\title{
TOXICITY OF BOLDO Peumus boldus MOLINA FOR Sitophilus zeamais MOTSCHULSKY AND Tribolium castaneum HERBST
}

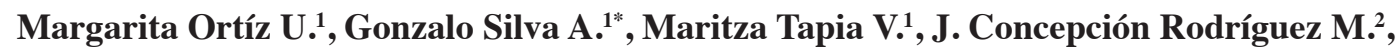 \\ Angel Lagunes T. ${ }^{2}$, Candelario Santillán-Ortega ${ }^{3}$, Agustín Robles-Bermúdez ${ }^{3}$, \\ and Sotero Aguilar-Medel ${ }^{4}$
}

The maize weevil (Sitophilus zeamais Motschulsky) and the red flour beetle (Tribolium castaneum Herbst) are two key pests of stored-grain products worldwide. The insecticidal activity of boldo (Peumus boldus Molina) powder, liquid ethanolic and hexanic extracts against $S$. zeamais and $T$. castaneum were evaluated under laboratory conditions. The evaluated variables were mortality, emergence of adult insects $\left(\mathrm{F}_{1}\right)$, and grain weight loss. The experimental design was completely randomized. The mortality in S. zeamais was $100 \%$ even at the lowest powder concentration $(0.5 \% \mathrm{w} / \mathrm{w})$, whereas emergence of $\mathrm{F}_{1}$ adult insects was $0 \%$ and grain weight loss was $\leq 0.08 \%$. For $T$. castaneum, only 8 and $16 \% \mathrm{w} / \mathrm{w}$ powder concentrations reached $100 \%$ mortality. The liquid ethanolic and hexanic extracts caused $100 \%$ mortality of $S$. zeamais, whereas only the ethanolic extract reached this value for $T$. castaneum. Therefore, the powder and the evaluated extracts of $P$. boldus were toxic for $S$. zeamais and T. castaneum and are promising against these and other stored-grain pests.

Key words: Botanical insecticides, stored grains, maize weevil, red flour beetle.

$\mathrm{S}$ tored grains are affected by several insect pests causing significant losses that may amount up to $50 \%$ of the harvest. In addition, pest damage to grain allows the entrance of pathogenic organisms such as fungus or bacteria (Regnault, 1997). The maize weevil (Sitophilus zeamais Motschulsky, Coleoptera: Curculionidae), rice weevil (Sitophilus oryzae Linnaeus, Coleoptera: Curculionidae), and grain moth (Ephestia kuehniella Zeller, Lepidoptera: Pyralidae) are three of the most important stored-grain pests in Chile (Larraín, 1994). Synthetic pesticides have been considered to be the most effective and easy to use tools against these insect pests (Huang and Subramanyam, 2005). However, their misuse has caused several problems such as the presence of high or illegal pesticide residues, human intoxication, and development of insect resistance (Roel and Vendramim, 2006).

The search for alternative methods includes using natural products that are both effective and

${ }^{1}$ Universidad de Concepción, Facultad de Agronomía, Av. Vicente Méndez 595, Chillán, Chile.

*Corresponding author (gosilva@udec.cl).

${ }^{2}$ Colegio de Postgraduados, Programa de Entomología y Acarología, km 36,5 Carretera México-Texcoco, Montecillo, Estado de México, México.

${ }^{3}$ Universidad Autónoma de Nayarit, Unidad Académica de Agricultura, km 9 Carr. Fed. Tepic-Compostela, Xalisco, Nayarit, México.

${ }^{4}$ Universidad Autónoma del Estado de México, Centro Universitario Tenancingo, Tenancingo, Estado de México, México.

Received: 2 February 2012.

Accepted: 3 June 2012. environmentally friendly, such as botanical insecticides (Roel and Vendramim, 2006). These compounds have been traditionally used in developing countries against stored-grain pests such as Sitophilus weevils (De Oliveira et al., 2003). Many of the secondary metabolites of plants act as insecticides, ovicidal, ovipositional, and feeding deterrents, and growth retardants (Pugazhvendan et al., 2009). Currently, research about their use as grain protectants involves tropical plant species; therefore, the search for Chilean flora with promising activity is needed.

The perennial boldo tree Peumus boldus Molina (Monimiaceae) is native to Chile and in powder form has insecticidal activity against $S$. zeamais (Páez et al., 1990; Silva et al., 2003; 2005; 2006; Pérez et al., 2007), third instar larvae of Spodoptera littoralis Boisduval (Lepidoptera: Noctuidae) (Zapata etal., 2006), Spodoptera frugiperda J.E. Smith (Lepidoptera: Noctuidae), Helicoverpa zea (Boddie) (Lepidoptera: Noctuidae) (Silva et al., 2010), as an extract against Xanthogaleruca luteola Müller (Coleoptera: Chrysomelidae) (Chiffelle $e t$ al., 2011), and as fungicide properties against Penicillum spp., Fusarium spp., Aspergillus niger Thieg., and A. flavus Link (Leite de Souza et al., 2005). The leaves of $P$. boldus contain a group of boldine alkaloids that have antioxidant, anti-inflammatory, and antipyretic properties (Vogel et al., 1999). However, the insecticidal properties of $P$. boldus extracts against $S$. zeamais and $T$. castaneum are not documented, so the aim of this research was to assess the insecticidal properties of $P$. boldus leaf powder and water, hexane, and ethanol extracts against $S$. zeamais and $T$. castaneum adults in the laboratory. 


\section{MATERIALS AND METHODS}

\section{Study site, plant material, and insects}

The study was carried out at the Laboratory of Entomology, Faculty of Agronomy, Universidad de Concepción in Chillán, Bío Bío Region, Chile.

Peumus boldus foliage was collected from trees in the park of the Universidad de Concepción, Chillán by following the criteria set out by Vogel et al. (1997).

Wheat (Triticum aestivum L.) flour was employed to rear T. castaneum, whereas maize (Zea mays L.) grains with $14 \%$ moisture were used as food substrate for $S$. zeamais. To avoid any previous infestation, grains were washed and dried in an oven (Memmert Gmbh, UNB 500, Schwabach, Germany) at $25{ }^{\circ} \mathrm{C}$ for $12 \mathrm{~h}$ and then frozen at $-4 \pm 1{ }^{\circ} \mathrm{C}$ for $48 \mathrm{~h}$ prior to use.

Insects for the bioassays were provided by the Laboratory of Entomology of the Universidad de Concepción, Chillán. They were reared in 1-L glass flasks containing maize for $S$. zeamais or wheat flour for $T$. castaneum as food, respectively. Insects were maintained in total darkness at a temperature of $25 \pm 1$ ${ }^{\circ} \mathrm{C}$ in a bioclimatic chamber (Memmert Gmbh, IPS 749, Schwabach, Germany).

\section{Bioassays}

Powder. Boldo leaves were washed and dried during 48 $\mathrm{h}$ at $40{ }^{\circ} \mathrm{C}$. Then, they were ground in an electric coffee grinder (Moulinex ultra 505) and passed through a 20 mesh $(0.841 \mathrm{~mm})$ (Dual Manufacturing, Chicago, Illinois, USA) sieve to produce fine powder.

For $S$. zeamais, $100 \mathrm{~g}$ of maize were placed in 250$\mathrm{mL}$ jars (Silva et al., 2003) before adding the respective treatment and hand shaken $1 \mathrm{~min}$ to homogenously cover the grain prior to infestation with 20 insect couples not older than $10 \mathrm{~d}$. Sex was determined with criteria proposed by Halstead (1963). After infestation, jars were transferred to a bioclimatic chamber $\left(25 \pm 1{ }^{\circ} \mathrm{C}, 60 \% \mathrm{HR}\right)$. The evaluated treatments were $0.5,1.0$ and $2.0 \% \mathrm{w} / \mathrm{w}$. All insects were removed $15 \mathrm{~d}$ after infestation (DAI) and percentage of mortality was registered and corrected for statistical analysis by Abbott's formula (Abbott, 1925). The maximum mortality level accepted for the untreated control was $10 \%$. Insects were considered dead when they failed to move after being prodded gently with a needle for $30 \mathrm{~s}$. Afterward, the percentage of adult emergence $\left(\mathrm{F}_{1}\right)$ was determined at 55 DAI. Grain weight loss was determined based on the difference between initial (100 g) and final weight.

For T. castaneum, $10 \mathrm{~g}$ of wheat flour were placed in 7-cm Petri dishes, mixing the flour with boldo foliage powder at $0.5,1.0,2.0,4.0,8.0$, and $16.0 \% \mathrm{w} / \mathrm{w}$ following the methodology by Chavez et al. (1992), and infesting each dish with 20 T. castaneum adults (unsexed 48-h-old). All dishes were located in a bioclimatic chamber at the same temperature as for $S$. zeamais. Mortality was recorded at 12 and $24 \mathrm{~h}$ and 3, 7, 14, and 21 DAI using the same criteria described above and corrected by Abbott's formula (Abbott, 1925).

Extracts. The aqueous extract was obtained with the methodology of Prates et al. (2003) by placing $10 \mathrm{~g}$ boldo powder in a jar with $100 \mathrm{~mL}$ distilled water at boiling point, covering, filtering after $24 \mathrm{~h}$ through Whatman $\mathrm{N}^{\circ} 10$ filter paper, and discarding the solid part. The extract was considered as the $100 \%$ stock compound. The ethanol and hexane extracts were obtained via Soxhlet extraction during $12 \mathrm{~h}$ (Kamaraj et al., 2008) and concentrated with a rotary evaporator (Fisatom, Sao Paulo, Brazil).

For $S$. zeamais, 6-mL test tubes with a $1 \mathrm{~mL}$ solution of each extract in distilled water and $0.2 \mathrm{~mL}$ of Tween ${ }^{\circledR}$ 20 surfactant (Kouninki et al., 2007) were employed at $0.25,0.5,1.0$, and $2.0 \% \mathrm{v} / \mathrm{v}$; an untreated control with 1 $\mathrm{mL}$ distilled water and the surfactant was covered with plastic film. Tubes were manually agitated for $1 \mathrm{~min}$ to properly cover the inner surface. The aqueous content was eliminated and test tubes were allowed to dry at room temperature for $1 \mathrm{~h}$. Then, 10 unsexed 48-h-old adult insects were placed in each tube. Treatments were kept in a bioclimatic chamber. Mortality was recorded at 12, 24, 48 , and $72 \mathrm{~h}$. In this bioassay every extract had a reference control consisting of a tube with its inner surface covered with the respective solvent and infested with insects.

For $T$. castaneum, $10 \mathrm{~g}$ wheat flour were mixed in $7-\mathrm{cm}$ Petri dishes with $2 \mathrm{~mL}$ of each extract solution at $0.5,1.0$, $2.0,4.0,8.0$, and $16.0 \% \mathrm{w} / \mathrm{v}$ and an untreated control with $1 \mathrm{~mL}$ distilled water; $2 \mathrm{~mL}$ Tween ${ }^{\circledR} 20$ surfactant was added to each treatment (Jbilou et al., 2006). Each dish was infested with 20 unsexed 48-h-old T. castaneum adults. Mortality was recorded at 12, 24, 48, and $72 \mathrm{~h}$ after infestation and corrected by Abbott's formula (Abbott, 1925). As in the $S$. zeamais bioassay, every extract had a reference control consisting of a Petri dish with wheat flour mixed only with the respective solvent and infested with insects.

\section{Experimental design and statistical analysis}

Treatments had 10 replicates and bioassays were replicated three times on separate days with a completely randomized experimental design. The response variables were transformed to arcsine $\sqrt{ } \mathrm{x} / 100$ prior to ANOVA $(\alpha=0.05)$ analysis with the SAS program (SAS Institute, 1990). Statistical differences were determined through Tukey tests $(\mathrm{P} \leq 0.05)$.

\section{RESULTS AND DISCUSSION}

\section{Effect of powder on $S$. zeamais}

All powder treatments caused $100 \%$ mortality (Table 1 ). At 1.0 and $2.0 \%$ concentrations mortality was similar to the results obtained by Páez et al. (1990), Silva et al. (2003; 2005; 2006), and Cruzat et al. (2009). However, at 
Table 1. Mortality, adult insect emergence $\left(F_{1}\right)$, and grain weight loss in maize treated with Peumus boldus powder at concentrations of 0.5, 1.0, and $2.0 \%(w / w)$ to control Sitophilus zeamais under laboratory conditions.

\begin{tabular}{lccl}
\hline Concentration & Mortality $^{1}$ & $\begin{array}{c}\text { Emergence } \\
\left(\mathrm{F}_{1}\right)\end{array}$ & Weight loss $^{1}$ \\
\hline \multicolumn{1}{c}{$\%$} & $100 \pm 0.0 \mathrm{a}$ & $0.0 \pm 0.0 \mathrm{~b}$ & $0.12 \pm 0.03 \mathrm{~b}$ \\
0.5 & $100 \pm 0.0 \mathrm{a}$ & $0.0 \pm 0.0 \mathrm{~b}$ & $0.09 \pm 0.001 \mathrm{bc}$ \\
1.0 & $100 \pm 0.0 \mathrm{a}$ & $0.0 \pm 0.0 \mathrm{~b}$ & $0.04 \pm 0.001 \mathrm{c}$ \\
2.0 & $0.0 \pm 0.0 \mathrm{~b}$ & $100 \pm 0.0 \mathrm{a}$ & $4.91 \pm 0.2 \mathrm{a}$ \\
Control $^{2}$ & &
\end{tabular}

'Values within a column with the same letter are not significantly different according to Tukey test $(\mathrm{P} \leq 0.05)$.

${ }^{2}$ Mortality in control was corrected by Abbott's formula (Abbott, 1925).

$0.5 \%$, we observed $100 \%$ mortality as compared to $\leq 30 \%$ reported by these researchers. According to Pérez et al. (2007), differences in toxic potency are probably related to the field-collection date of plant material, and there was no emergence of $F_{1}$ adults. In all treatments with powder, grain weight loss was $<0.5 \%$, which is significantly lower $(\mathrm{P} \leq 0.05)$ than the untreated control (Table 1).

\section{Effect of powder on $\boldsymbol{T}$. castaneum}

The insecticidal effect of $P$. boldus powder against $T$. castaneum adults increased over time (Table 2). However, this species is less affected than $S$. zeamais for which concentrations of 8.0 and $16.0 \%$ lead to $100 \%$ mortality at 14 DAI. The reduced sensibility of $T$. castaneum to vegetable powders agrees with data found by Denloye $e t$ al. (2010), who obtained higher mortality with extracts $\left(\mathrm{LC}_{50}=0.04 \mathrm{~g} \mathrm{~L}^{-1}\right)$ than with powders $\left(\mathrm{LC}_{50}=250 \mathrm{~g} \mathrm{~kg}^{-1}\right)$ using Chenopodium ambrosioides L. (Chenopodiaceae). Peumus boldus powder is more potent against T. castaneum than other vegetable powders derived from plants such as Khaya senegalensis (Bamaiyi and Bolanta, 2006) or Punica granatum, and Murraya koenigii (Gandhi et al., 2010). Furthermore, plant powder gives a greenish color to the treated flour, thus affecting its quality for human consumption. This is why some researchers suggest not mixing powder with flour (Kordan et al., 2003; Husain and Hasan, 2008; Pugazhvendan et al., 2009).

\section{Extracts}

Sitophilus zeamais. The hexanic extract was the most toxic after $24 \mathrm{~h}$ exposure in all evaluated concentrations and caused $100 \%$ mortality (Table 3 ). The aqueous and ethanolic extracts reached $100 \%$ mortality at $72 \mathrm{~h}$. Considering the polarity of used solvents (water is polar, ethanol has intermediate polarity, and hexane is nonpolar), we inferred that the insecticidal properties of $P$. boldus extracts are due to polar and non-polar molecules because all extracts reached $100 \%$ mortality. It is probable that insecticidal properties of boldo extracts are due to a group of molecules with joint action similar to neem (Azadirachta indica J. [Meliaceae]) (Schmutterer, 1990). The highest toxicity of hexanic extract as compared to ethanolic extract agrees with Hincapie et al. (2008), who evaluated Annona muricata L. (Annonaceae) extracts at a $5 \%$ concentration and obtained $100 \%$ S. zeamais mortality with the hexanic extract, while the ethanolic extract under the same conditions cause no mortality (0\%). We estimated that $P$. boldus has a higher insecticidal potency than other plant extracts such as Brassica napus (L.) (Brassicaceae) (Salem et al., 2007), Clerodendrum inerme L. (Verbenaceae), Withania somnifera L. (Solanaceae), Gliricidia sepia L. (Fabaceae), Cassia tora L. (Caesalpiniaceae), and Eupatorium odoratum L. (Asteraceae) (Yankanchi and Gadache, 2010). In these cases, at least a $5 \%$ concentration was needed to reach $80 \%$ mortality. Using Jatropa curcas L. (Euphorbiaceae) extracts, a $20 \%$ concentration was required to reach a 70 to $90 \%$ mortality (Asmanizar and Idris, 2012).

Tribolium castaneum. Plant powder extracts also gave a greenish color to the treated flour. The aqueous extracts caused no mortality $(0.0 \%)$ in all the evaluated concentrations. The hexanic extract killed $6.7 \%$ of treated individuals at $16.0 \%$ concentration (Table 4 ). The highest mortality $(100 \%)$ was achieved by the ethanolic extract during $12 \mathrm{~h}$ exposure at concentrations $\geq 2 \%$. It seems that $P$. boldus is more toxic than other plant extracts such as Manilkara zapota (L.) (Sapotaceae) (Osman et al., 2011), Chrysanthemum spp. (Asteraceae) (Haouas et al., 2008), Hyptis spicigera Lam. (Labiatae) (Othira et al., 2009), Peganum harmala L. (Nitrariaceae) (Jbilou and Sayah, 2008), and Mantis alcaduriaei (Spach) Briq. \& Cavill (Asteraceae) (Boussaada et al., 2008) in which only larval

Table 2. Mortality of Tribolium castaneum adults in flour wheat mixed with Peumus boldus powder at concentrations of $0.5,1.0,2.0,4.0,8.0$, and 16.0\% (w/w) under laboratory conditions.

\begin{tabular}{|c|c|c|c|c|c|c|}
\hline \multirow[b]{2}{*}{ Concentration } & \multicolumn{6}{|c|}{ Mortality $^{1}$} \\
\hline & $12 \mathrm{~h}$ & $24 \mathrm{~h}$ & $3 \mathrm{~d}$ & $7 d$ & $14 \mathrm{~d}$ & $21 \mathrm{~d}$ \\
\hline$\%$ & & & 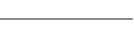 & & & \\
\hline \multicolumn{7}{|l|}{ Control $^{2}$} \\
\hline$(0.0)$ & $0.0 \pm 0.0$ & $0.0 \pm 0.0$ & $0.0 \pm 0.0$ & $0.0 \pm 0.0$ & $0.0 \pm 0.0$ & $0.0 \pm 0.0$ \\
\hline 0.5 & $0.0 \pm 0.0 \mathrm{~b}$ & $3.5 \pm 0.27 \mathrm{a}$ & $7.0 \pm 0.22 \mathrm{c}$ & $11.1 \pm 0.2 \mathrm{~d}$ & $13.7 \pm 0.2 \mathrm{e}$ & $14.5 \pm 0.25 \mathrm{e}$ \\
\hline 1.0 & $0.0 \pm 0.0 \mathrm{~b}$ & $3.5 \pm 0.22 \mathrm{a}$ & $10.5 \pm 0.55 c$ & $22.2 \pm 1.25 \mathrm{~d}$ & $41.1 \pm 5.5 \mathrm{~d}$ & $41.6 \pm 5.5 d$ \\
\hline 2.0 & $1.7 \pm 0.22 b$ & $5.2 \pm 0.32 \mathrm{a}$ & $10.5 \pm 0.90 c$ & $46.2 \pm 2.75 c$ & $66.6 \pm 6.66 c$ & $64.5 \pm 6.00 \mathrm{c}$ \\
\hline 4.0 & $5.2 \pm 0.56 a$ & $8.7 \pm 0.44 a$ & $26.3 \pm 1.75 b$ & $75.9 \pm 2.90 b$ & $80.3 \pm 5.5 b$ & $79.1 \pm 2.50 b$ \\
\hline 8.0 & $5.2 \pm 0.56 a$ & $10.5 \pm 0.55 a$ & $26.3 \pm 2.00 \mathrm{~b}$ & $98.1 \pm 5.5 \mathrm{a}$ & $100 \pm 0.0 \mathrm{a}$ & $100 \pm 0.0 \mathrm{a}$ \\
\hline 16.0 & $5.2 \pm 0.56 a$ & $12.2 \pm 0.60 \mathrm{a}$ & $64.9 \pm 5.55 a$ & $100 \pm 0.0 \mathrm{a}$ & $100 \pm 0.0 \mathrm{a}$ & $100 \pm 0.0 \mathrm{a}$ \\
\hline
\end{tabular}

${ }^{1}$ Values within a column with the same letter are not significantly different according to Tukey test $(\mathrm{P} \leq 0.05)$.

${ }^{2}$ Mortality in control was corrected by Abbott's formula (Abbott, 1925). 
Table 3. Mortality of Sitophilus zeamais adults treated with Peumus boldus extracts in water, hexane, and ethanol at concentrations of $0.5,1.0$, and $\mathbf{2 . 0 \%}(\mathrm{w} / \mathrm{v})$ under laboratory conditions.

\begin{tabular}{|c|c|c|c|c|c|}
\hline \multirow[b]{2}{*}{ Extract } & \multirow[b]{2}{*}{$\begin{array}{l}\text { Concen- } \\
\text { tration }\end{array}$} & \multicolumn{4}{|c|}{ Mortality $^{1}$} \\
\hline & & $12 \mathrm{~h}$ & $24 \mathrm{~h}$ & $48 \mathrm{~h}$ & $72 \mathrm{~h}$ \\
\hline & & & $-\%$ & $\mathrm{w}$ & \\
\hline \multirow[t]{4}{*}{ Water } & Control $^{2}$ & $0.0 \pm 0.0$ & $0.0 \pm 0.0$ & $0.0 \pm 0.0$ & $0.0 \pm 0.0$ \\
\hline & 0.5 & $0.0 \pm 0.0 \mathrm{~b}$ & $0.0 \pm 0.0 \mathrm{~b}$ & $46.7 \pm 3.3 \mathrm{a}$ & $100 \pm 0.0 \mathrm{a}$ \\
\hline & 1.0 & $0.0 \pm 0.0 \mathrm{~b}$ & $0.0 \pm 0.0 \mathrm{~b}$ & $46.7 \pm 3.5 \mathrm{a}$ & $100 \pm 0.0 \mathrm{a}$ \\
\hline & 2.0 & $13.3 \pm 1.1 \mathrm{a}$ & $13.3 \pm 1.1 \mathrm{a}$ & $66.7 \pm 4.0 \mathrm{a}$ & $100 \pm 0.0 \mathrm{a}$ \\
\hline \multirow[t]{4}{*}{ Ethanol } & Control $^{2}$ & $0.0 \pm 0.0$ & $0.0 \pm 0.0$ & $0.0 \pm 0.0$ & $0.0 \pm 0.0$ \\
\hline & 0.5 & $0.0 \pm 0.0 \mathrm{~b}$ & $0.0 \pm 0.0 \mathrm{~b}$ & $46.7 \pm 3.0 \mathrm{a}$ & $100 \pm 0.0 \mathrm{a}$ \\
\hline & 1.0 & $0.0 \pm 0.0 \mathrm{~b}$ & $0.0 \pm 0.0 \mathrm{~b}$ & $46.7 \pm 3.0 \mathrm{a}$ & $100 \pm 0.0 \mathrm{a}$ \\
\hline & 2.0 & $13.33 \pm 1.1 \mathrm{a}$ & $13.33 \pm 1.1 \mathrm{a}$ & $66.7 \pm 5.5 \mathrm{a}$ & $100 \pm 0.0 \mathrm{a}$ \\
\hline \multirow[t]{4}{*}{ Hexane } & Control $^{2}$ & $0.0 \pm 0.0$ & $0.0 \pm 0.0$ & $0.0 \pm 0.0$ & $0.0 \pm 0.0$ \\
\hline & 0.5 & $0.0 \pm 0.0 \mathrm{~b}$ & $100 \pm 0.0 \mathrm{a}$ & - & - \\
\hline & 1.0 & $0.0 \pm 0.0 \mathrm{~b}$ & $100 \pm 0.0 \mathrm{a}$ & - & - \\
\hline & 2.0 & $26.7 \pm 2.25 \mathrm{a}$ & $100 \pm 0.0 \mathrm{a}$ & - & - \\
\hline
\end{tabular}

${ }^{1}$ Values within a column with the same letter are not significantly different according to Tukey test $(\mathrm{P} \leq 0.05)$

${ }^{2}$ Mortality in control was corrected by Abbott's formula (Abbott, 1925).

Table 4. Mortality of Tribolium castaneum adults treated with wheat flour mixed with Peumus boldus extracts in water ${ }^{1}$, hexane, and ethanol at concentrations of $\mathbf{0 . 5}, 1.0,2.0,4.0,8.0$, and $16.0 \%(w / v)$ under laboratory conditions.

\begin{tabular}{cccccc}
\hline & & \multicolumn{4}{c}{ Mortality $^{2}$} \\
\cline { 3 - 6 } Extract & $\begin{array}{c}\text { Concen- } \\
\text { tration }\end{array}$ & $12 \mathrm{~h}$ & $24 \mathrm{~h}$ & $48 \mathrm{~h}$ & $72 \mathrm{~h}$ \\
\hline \multirow{5}{*}{ Ethanol } & & & \multicolumn{4}{c}{$\% \mathrm{w} / \mathrm{W}$} & \\
& $0.0^{3}$ & $0.0 \pm 0.0 \mathrm{~b}$ & $0.0 \pm 0.0 \mathrm{~b}$ & $0.0 \pm 0.0 \mathrm{~b}$ & $0.0 \pm 0.0 \mathrm{~b}$ \\
& 0.5 & $22.8 \pm 3.3 \mathrm{c}$ & $31.5 \pm 3.2 \mathrm{c}$ & $33.3 \pm 3.1 \mathrm{c}$ & $33.3 \pm 3.0 \mathrm{c}$ \\
& 1.0 & $47.3 \pm 3.5 \mathrm{~b}$ & $59.6 \pm 3.0 \mathrm{~b}$ & $68.4 \pm 2.6 \mathrm{~b}$ & $73.6 \pm 2.2 \mathrm{~b}$ \\
& 2.0 & $98.2 \pm 0.01 \mathrm{a}$ & $100 \pm 0.0 \mathrm{a}$ & $100 \pm 0.0 \mathrm{a}$ & $100 \pm 0.0 \mathrm{a}$ \\
& 4.0 & $100 \pm 0.0 \mathrm{a}$ & $100 \pm 0.0 \mathrm{a}$ & $100 \pm 0.0 \mathrm{a}$ & $100 \pm 0.0 \mathrm{a}$ \\
& 8.0 & $100 \pm 0.0 \mathrm{a}$ & $100 \pm 0.0 \mathrm{a}$ & $100 \pm 0.0 \mathrm{a}$ & $100 \pm 0.0 \mathrm{a}$ \\
& 16.0 & $100 \pm 0.0 \mathrm{a}$ & $100 \pm 0.0 \mathrm{a}$ & $100 \pm 0.0 \mathrm{a}$ & $100 \pm 0.0 \mathrm{a}$ \\
& $0.0^{3}$ & $0.0 \pm 0.0 \mathrm{~b}$ & $0.0 \pm 0.0 \mathrm{~b}$ & $0.0 \pm 0.0 \mathrm{~b}$ & $0.0 \pm 0.0 \mathrm{~b}$ \\
& 0.5 & $0.0 \pm 0.0 \mathrm{~b}$ & $0.0 \pm 0.0 \mathrm{~b}$ & $0.0 \pm 0.0 \mathrm{~b}$ & $0.0 \pm 0.0 \mathrm{~b}$ \\
& 1.0 & $0.0 \pm 0.0 \mathrm{~b}$ & $0.0 \pm 0.0 \mathrm{~b}$ & $0.0 \pm 0.0 \mathrm{~b}$ & $0.0 \pm 0.0 \mathrm{~b}$ \\
& 2.0 & $0.0 \pm 0.0 \mathrm{~b}$ & $0.0 \pm 0.0 \mathrm{~b}$ & $0.0 \pm 0.0 \mathrm{~b}$ & $0.0 \pm 0.0 \mathrm{~b}$ \\
& 4.0 & $0.0 \pm 0.0 \mathrm{~b}$ & $0.0 \pm 0.0 \mathrm{~b}$ & $0.0 \pm 0.0 \mathrm{~b}$ & $0.0 \pm 0.0 \mathrm{~b}$ \\
& 8.0 & $0.0 \pm 0.0 \mathrm{~b}$ & $0.0 \pm 0.0 \mathrm{~b}$ & $0.0 \pm 0.0 \mathrm{~b}$ & $0.0 \pm 0.0 \mathrm{~b}$ \\
& 16.0 & $5.0 \pm 1.0 \mathrm{a}$ & $6.7 \pm 1.2 \mathrm{a}$ & $6.7 \pm 1.2 \mathrm{a}$ & $6.7 \pm 1.2 \mathrm{a}$
\end{tabular}

${ }^{1}$ The aqueous extracts caused no mortality $(0.0 \%)$ in all the evaluated concentrations.

${ }^{2}$ Values within a column with the same letter are not significantly different according to Tukey test $\mathrm{P} \leq 0.05$ ).

${ }^{3}$ Mortality in control was corrected by Abbott's formula (Abbott, 1925).

mortality was documented. Some researchers suggest that plant extracts are powerful repellents but not promising contact insecticides against T. castaneum (Kanvil et al., 2006; Saidana et al., 2007).

\section{CONCLUSIONS}

The foliage powder of Peumus boldus is more effective against Sitophilus zeamais as compared to Tribolium castaneum under laboratory conditions. The hexanic and ethanolic extracts are more effective against $S$. zeamais and $T$. castaneum than the aqueous extract. These results must be field-validated in order to evaluate their usefulness as a chemical tool against these insect pest species.
Toxicidad del boldo, Peumus boldus Molina, sobre Sitophilus zeamais Motschulsky y Tribolium castaneum Herbst. El gorgojo del maíz (Sitophilus zeamais Motschulsky) y el gorgojo castaño de la harina (Tribolium castaneum Herbst) son plagas primarias de productos almacenados a nivel mundial. Se evaluó en laboratorio la actividad insecticida de polvo y extractos líquidos etanólicos y hexánicos del boldo (Peumus boldus Molina) sobre $S$. zeamais y $T$. castaneum. Las variables evaluadas fueron mortalidad y emergencia de insectos adultos $\left(\mathrm{F}_{1}\right)$ y pérdida de peso de los granos con un diseño experimental completamente al azar. La mortalidad en $S$. zeamais fue $100 \%$, incluso con la concentración menor $(0,5 \% \mathrm{p} / \mathrm{p})$ mientras que la emergencia de insectos adultos y la pérdida de peso de granos de maíz fue $\leq 0,08 \%$. Para T. castaneum sólo las concentraciones de 8 y $16 \%$ p/p de polvo causaron una mortalidad de $100 \%$. Los extractos en agua, etanol, y hexano tuvieron un efecto insecticida de $100 \%$ en S. zeamais, mientras que en T. castaneum sólo el extracto en etanol alcanzó este valor. Por lo tanto, el polvo y los extractos evaluados de $P$. boldus presentan actividad insecticida contra $S$. zeamais y $T$. castaneum y son promisorios para utilizarse contra éstas y otras plagas de granos almacenados.

Palabras clave: insecticidas vegetales, granos almacenados, gorgojo del maíz, gorgojo castaño de la harina.

\section{LITERATURE CITED}

Abbott, W.A. 1925. A method for computing the effectiveness of an insecticide. Journal of Economic Entomology 18:265-267.

Asmanizar, A.D., and A.B. Idris. 2012. Evaluation of Jatropha curcas and Annona muricata seed crude extracts against Sitophilus zeamais infesting stored rice. Journal of Entomology 9:13-22.

Bamaiyi, L.J., and F.F. Bolanta. 2006. Evaluation of Khaya senegalensis products in the control of Tribolium castaneum on stored sorghum. Archives of Phytopathology and Plant Protection 39:99-103.

Boussaada, O., M.B. Halima, S. Ammar, D. Haouas, Z. Mighri, and A. Noureddine. 2008. Insecticidal activity of some asteraceae plant extracts against Tribolium confusum. Bulletin of Insectology 61:283-289.

Chavez, G., F. Nuñez, y J. Calle. 1992. Evaluación de la acción insecticida de la rapanona sobre Tribolium castaneum (Herbst). Acta Biológica Colombiana 2:139-148.

Chiffelle, I., A. Huerta, R. Jiménez, and J.E. Araya. 2011. Proximal analysis and toxicity of extracts from young and mature leaves of the boldo tree (Peumus boldus) on elm leaf beetle (Xanthogaleruca luteola). Canadian Journal of Forest Research 41:2259-2266.

Cruzat, M., G. Silva, H. Serri, y R. Hepp. 2009. Protección de ocho cultivares de trigo con polvo de Peumus boldus Molina contra Sitophilus zeamais Motschulsky. IDESIA (Chile) 37:39-46.

Denloye, A., W.A. Makanjuola, O. Teslim, O.A. Alafia, A. Kasali, and A. Eshilokun. 2010. Toxicity of Chenopodium ambrosioides L. (Chenopodiaceae) products from Nigeria against three storage insects. Journal of Plant Protection Research 50:379-384.

De Oliveira, S., J. Vendramim, J. Ribeiro, e J. Barbosa. 2003. Bioatividade de diversos pós de origem vegetal emrelaçao a Sitophilus zeamais Mots. (Coleoptera: Curculionidae). Ciênciae Agrotecnologia 27:1231-1236. 
Gandhi, N., S. Pillai, and P. Patel. 2010. Efficacy of pulverized Punica granatum (Lythraceae) and Murraya koenigii (Rutaceae) leaves against stored grain pest Tribolium castaneum (Coleoptera: Tenebrionidae). International Journal of Agriculture and Biology 12:616-620.

Haouas, D., M.B. Halima-Kamel, and M.H. Hamouda. 2008. Insecticidal activity of flower and leaf extracts from Chrysanthemum species against Tribolium confusum. Tunisian Journal of Plant Protection 3:87-93.

Halstead, W.A. 1963. External sex differences in stored-products Coleoptera. Bulletin of Entomological Research 54:119-134.

Hincapie, C., D. Lopera, and M. Ceballos. 2008. Actividad insecticida de extractos de semilla de Annona muricata (Anonaceae) sobre Sitophilus zeamais (Coleoptera: Curculionidae). Revista Colombiana de Entomología 34:76-82.

Huang, F., and B. Subramanyam. 2005. Management of five storedproduct insects in wheat with pirimiphos-methyl and pirimiphosmethyl plus synergized pyrethrins. Pest Management Science 61:356-362.

Husain, M.M., and M.R. Hasan. 2008. Repellency of indigenous plant, Bhat (Clerodendron viscosum Vent.) leaf on Tribolium confusum Duval. Bangladesh Journal of Scientific and Industrial Research 43:267-272.

Jbilou, R., A. Ennabili, and F. Sayah. 2006. Insecticidal activity of four medicinal plant extracts against Tribolium castaneum (Herbst) (Coleoptera: Tenebrionidae). African Journal of Biotechnology 5:936-940.

Jbilou, R., and F. Sayah. 2008. Effects of Peganum harmala (Zygophyllaceae) seed extract on the development of Tribolium castaneum (Coleoptera: Tenebrionidae). International Journal of Tropical Insect Science 27:199-209.

Kamaraj, C., A.A. Rahuman, and A.Vagaban. 2008. Antifeedant and larvicidal effects of plant extracts against Spodoptera litura (F.), Aedes aegypti L. and Culex quinquefasciatus Say. Parasitology Research 103:325-331.

Kanvil, S., G. Jilani, and J.R. Rehman. 2006. Repellency of petroleum ether extract of some indigenous plants against Tribolium castaneum (Herbst) (Coleoptera: Tenebrionidae). Pakistan Journal of Zoology 38:233-238.

Kordan, K., D. Ciepielewska, and M. Nietupski. 2003. Deterrent activity of plant powders on grain weevil (Sitophilus granarius L.) and red flour beetle (Tribolium castaneum Herbst). Polish Journal of Natural Sciences 14:265-271.

Kouninki, H., T. Hance, F.A. Noudjou, G. Lognay, F. Malaisse, M.B. Ngassoum, et al. 2007. Toxicity of some terpenoids of essential oils of Xylopia aethiopica from Cameroon against Sitophilus zeamais Motschulsky. Journal of Applied Entomology 131:269274.

Larraín, P. 1994. Manejo integrado de plagas en granos almacenados. Investigación y Progreso Agropecuario La Platina 81:10-16.

Leite de Souza, E., E. de Oliveira, K.R. de Luna, and C. Paiva de Souza. 2005. Inhibitory action of some essential oils and phytochemicals on the growth of various mold isolated of from foods. Brazilian Archives of Biology and Biotechnology 48:245250 .

Osman, M., M. Aziz, M. Habib, and M. Karim. 2011. Pesticidal evaluation of Manilkara zapota (L.) against Tribolium castaneum (Herbst). Agriculturae Conspectus Scientificus 76:143-146.

Othira, J.O., L.A. Onek, L.A. Deng, and E.O. Omolo. 2009. Insecticidal potency of Hyptis spicigera preparations against Sitophilus zeamais (I.) and Tribolium castaneum (Herbst) on stored maize grains. African Journal of Agricultural Research 4:187-192.
Páez, A., A. Lagunes, J.L. Carrillo, y J.C. Rodríguez. 1990. Polvos vegetales y minerales inertes para el combate del gorgojo Sitophilus zeamais (Colepotera: Curculionidae) en maíz almacenado. Agrociencia 3:35-46.

Pérez, F., G. Silva, M. Tapia, y R. Hepp. 2007. Variación anual de las propiedades insecticidas de Peumus boldus sobre Sitophilus zeamais. Pesquisa Agropecuaria Brasileira 42:633-639.

Prates, H., P.A. Viana, e J.M. Waquil. 2003. Atividade de extrato aquoso de folhas de nim (Azidarachta indica) sobre Spodoptera frugiperda. Pesquisa Agropecuaria Brasileira 38:437-439.

Pugazhvendan, S.R., K. Elumalai, P. Ronald Ross, and M. Soundararajan. 2009. Repellent activity of chosen plant species against Tribolium castaneum. World Journal of Zoology 4:188190.

Regnault, R.C. 1997. The potential of botanical essential oils for insect pest control. Integrated Pest Management Review 2:25-34.

Roel, A., e J.D. Vendramim. 2006. Efeito residual do extrato acetato de etila de Trichilia pallida Swartz (Meliaceae) para lagartas de diferentes idades de Spodoptera frugiperda (J.E. Smith, 1797) (Lepidoptera: Noctuidae). Ciencia Rural 36:1049-1054.

Saidana, D., M.B. Halima-Kamel, M.A. Mahjoub, D. Houas, Z. Mighri, and A.N. Helal. 2007. Insecticidal activities of Tunisian halophytic plant extracts against larvae and adults of Tribolium confusum. Tropicultura 25:193-199.

Salem, S.A., R.G. Abou-Ela, M.M. Matter, and M.Y. El-Kholy. 2007. Entomocidal effect of Brassica napus extracts on two store pests, Sitophilus oryzae (L.) and Rizopherta dominica (Fab.) (Coleoptera). Journal of Applied Sciences Research 3:317-322.

SAS Institute. 1990. UNIX Environment and derivatives. Version 6. SAS Institute Inc., Cary, North Carolina, USA.

Schmutterer, H. 1990. Properties and potential of natural pesticides from the neem tree, Azadirachta indica. Annual Review of Entomology 35:271-297.

Silva, G., A. Lagunes, y J.C. Rodríguez. 2003. Control de Sitophilus zeamais (Coleoptera: Curculionidae) con polvos vegetales solos y en mezcla con carbonato de calcio. Ciencia e Investigación Agraria 30:153-160.

Silva, G., O. Orrego, R. Hepp, y M. Tapia. 2005. Búsqueda de plantas con propiedades insecticidas para el control de Sitophilus zeamais Motschulsky en maíz almacenado. Pesquisa Agropecuaria Brasileira 40:11-17

Silva, G., J.C. Rodríguez, A. Lagunes, C. Llanderal, R. Alatorre, C. Blanco, and A.M. Shelton. 2010. Bioactivity of boldo (Peumus boldus Molina) (Laurales: Monimiaceae) on Spodoptera frugiperda (J.E. Smith) and Helicoverpa zea (Boddie) (Lepidoptera: Noctuidae). Southwestern Entomologist 35:215231.

Silva, G., M. Tapia, R. Hepp, G. Bustos, y F. Osses. 2006. Evaluación de boldo (Peumus boldus Molina) y cal para el control de Sitophilus zeamais Motschulsky. Agrociencia 40:219-228.

Vogel, H., I. Razmilic, y U. Doll. 1997. Contenido de aceite esencial y alcaloides en diferentes poblaciones de boldo (Peumus boldus Mol.) Ciencia e Investigación Agraria 24:1-6.

Vogel, H., I. Razmilic, P. Muñoz, U. Doll, and J. San Martín. 1999. Studies of genetic variation of essential oil and alkaloid content in Boldo (Peumus boldus). Planta Medica 65:90-91.

Yankanchi, S.R., and H. Gadache. 2010. Grain protectant efficacy of certain plant extracts against rice weevil, Sitophilus oryzae L. (Coleoptera: Curculionidae). Journal of Biopesticides 3:511-513.

Zapata, N., F. Budia, G. Silva, E. Viñuela, y P. Medina. 2006. Actividad antialimentaria de Maytenus boaria Mol., Peumus boldus Mol. y Quillaja saponaria Mol. sobre Spodoptera littoralis Boisd. Boletín de Sanidad Vegetal Plagas 32:125-135. 